\title{
Risk factors for Leishmania chagasi infection in an urban area of Minas Gerais State
}

\author{
Fatores de risco para infecção por Leishmania chagasi em \\ uma área urbana do Estado de Minas Gerais
}

\author{
Elizabeth Castro Moreno ${ }^{1}$, Maria Norma Melo², Odair Genaro $†$, José Roberto Lambertucci³ \\ José Carlos Serufo ${ }^{3}$, Antero Silva Ribeiro Andrade ${ }^{4}$, Carlos Mauricio Figueiredo Antunes ${ }^{2,5}$ \\ and Mariângela Carneiro ${ }^{2}$
}

\begin{abstract}
In order to understand the determinants of human infection by Leishmania chagasi in an urban area, a cross-sectional population based study was conducted using molecular and serologic methods to identify infection. Participants were interviewed using a pre-coded questionnaire. Two criteria were tested to identify risk factors: Model 1-including all participants positive in hybridization by Leishmania donovani complex probe; Model 2-including all participants positive for hybridization and at least one serologic test. In Model 1, the variables associated with infection were: ownership of birds, time spent outside house between 6:00-10:00 PM and garbage not collected. In Model 2, the variables associated with infection were: family with knowledge of the vector, garbage not collected, garbage not removed or buried, ownership of birds and eroded areas in the neighborhood. The risk factors identified were associated with household conditions, presence of animals and the likelihood of contact with phlebotomine sandflies.
\end{abstract}

Key-words: Visceral leishmaniasis. Kala-Azar. Leishmania chagasi. Asymptomatic infection. Risk factors.

\section{RESUMO}

Com o objetivo de identificar os determinantes da infecção humana por Leishmania chagasi em uma área urbana, foi realizado um estudo seccional de base populacional utilizando-se métodos moleculares e sorológicos para identificar a infecção. Os participantes foram entrevistados utilizando-se questionário pré-codificado. Dois critérios foram testados para identificar os fatores de risco: Modelo 1- incluindo todos os participantes positivos na hibridização com sonda para o complexo Leishmania donovani; Modelo 2-incluindo todos os participantes positivos na hibridização e em pelo menos um teste sorológico. No Modelo 1, as variáveis associadas à infecção foram: criar pássaros, encontrar-se fora de casa entre 18:00-22:00h e não ter o lixo coletado. No Modelo 2, as variáveis associadas à infecção foram: família conhecer o vetor, não ter o lixo coletado, lixo não removido ou queimado, criar pássaros, proximidade de áreas erodidas. Os fatores de risco identificados foram associados às condições das moradias, presença de animais e probabilidade de contato com flebotomíneos.

Palavras-chaves: Leishmaniose visceral. Calazar. Leishmania chagasi. Infecção assintomática. Fatores de risco.

American visceral leishmaniasis (AVL), caused by Leishmania (Leishmania) chagasi, is transmitted by the phlebotomine sand fly Lutzomyia longipalpis. In the last 10 years the disease has become a serious public health problem in Brazil due to the high prevalence of canine infection and the increase of human cases in peri-urban and urban areas of large cities ${ }^{3}$.

Although $90 \%$ of clinical cases of AVL occur in the Northeastern region of the Country, in recent years the incidence of cases has increased in Southeastern states like Minas Gerais,

1. Fundação Nacional de Saúde de Minas Gerais, Belo Horizonte, MG. 2. Departamento de Parasitologia do Instituto de Ciências Biológicas da Universidade Federal de Minas Gerais, Belo Horizonte, MG. 3. Departamento de Clínica Médica da Faculdade de Medicina da Universidade Federal de Minas Gerais, Belo Horizonte, MG. 4. Comissão Nacional de Energia Nuclear do Centro de Desenvolvimento da Tecnologia Nuclear. 5. Santa Casa de Belo Horizonte, Belo Horizonte, MG, Brasil. †in memoriam.

Partially supported by Ministry of Health, Brazil, project Cenepi/Vigisus (06-MG-055-99), Conselho Nacional de Desenvolvimento Científico e Tecnológico (400186/1998-5) Address to: Dr ${ }^{a}$ Mariângela Carneiro. Dept ${ }^{\circ}$ de Parasitologia/ICB/UFMG. Av Antônio Carlos 6627, Caixa Postal 486, $31279-901$ Belo Horizonte, MG, Brasil.

Tel: 5531 3499-2839, Fax: 5531 3499-2860

e-mail: mcarneir@mono.icb.ufmg.br

Recebido para publicação em 28/7/2004

Aceito em 12/7/2005 
where the disease have been reported in several cities including Belo Horizonte, the state capital ${ }^{19}$.

Knowledge of AVL epidemiology in Brazil, including the definition and the evaluation of control measures, is based almost entirely on the description and study of clinical cases. Recent studies have revealed large number of individuals harboring asymptomatic $L$. chagasi infection, with patients that do not develop the classic symptoms and signs of the disease ${ }^{56781520}$.

One of the most important drawbacks in investigating L. chagasi infection is the difficulty to diagnose patients in the asymptomatic and sub-clinical phases; this can be explained by the presence of low antibody levels and reduced parasite $\operatorname{load}^{422}$

Epidemiologic studies addressing this issue have been conducted in endemic areas in the last decade; however, because they were conducted with specific groups, such as children less than 15 years old or families and neighbours of clinical cases, they have low external validity. The results of such studies cannot be extrapolated to the general population ${ }^{57115}$. The present investigation is the first attempt to identify risk factors associated with $L$. chagasi infection in an urban area, using a population-based study.

The pattern of spread of AVL has been overlooked in densely populated urban areas, where social networks and interactions between housing and the natural environment are more complex than in rural $\operatorname{areas}^{26}$. Disease control strategies that target the canine reservoirs and phlebotomine vectors have failed to interrupt transmission and prevent the expansion of the disease, particularly in urban $\operatorname{areas}^{1025}$. A more profound knowledge of the determinants of the $L$. chagasi transmission cycle in urban areas is required. The purpose of the present investigation was to identify the risk factors associated with $L$. chagasi infection, in order to understand the determinants of human AVL acquisition in an urban area. Molecular and serologic methods were used to identify participants infected by L. chagasi.

\section{PATIENTS AND METHODS}

Study area. This study was conducted in General Carneiro, Sabará (19.9 9'S, 43.8 E), a town of 19,500 inhabitants situated within the Belo Horizonte metropolitan area, state of Minas Gerais. Despite the urban localization of General Carneiro the population retains some rural characteristics such as keeping dogs and raising chickens, pigs and other livestock in their yards.

Canine serologic surveys conducted routinely by the local Public Health Services have revealed prevalence rates of 5-10\%. Thirteen human cases of AVL were reported from General Carneiro between 1989 and 2004, with one fatal case.

Study design and population. The study was approved by the Ethical Review Board of the Federal University of Minas Gerais. All participants or their legal guardians, in the case of minors, were required to sign the Informed Consent Form before data collection. Medical attendance and treatment were guaranteed for all participants if necessary.

The study was carried out in two distinct phases: first, a crosssectional population survey and secondly, a follow-up study with a representative subset of participants identified as positive and negative in the survey. The cross-sectional population survey was carried out in 1998 with 1,604 habitants, as described elsewhere ${ }^{20}$. The sample size was calculated based on the following parameters: 1) an estimated human infection prevalence of 3.1\% (from a study conducted in Bahia State; 2) precision of the estimate prevalence ranging from $2.3 \%$ to $3.9 \%$; 3) $\alpha$ error $=0.05$; 4) population of study area $=19,500$ inhabitants. For operational reasons, households were used as sampling units. A simple random sample of city blocks was selected proportional to the existent blocks, and within each selected block, a random sample of households, proportional to the number of existent houses, was drawn. All inhabitants of the selected houses were eligible and invited to participate in the study.

The member responsible for the family was interviewed using a precoded questionnaire especially developed for this study. The information collected included details of the respondent and all other participating family members. During the interview a blood sample was collected from each participant by fingerprick onto filter paper. The diagnostic tests performed were: enzyme-linked immunobsorbent assay (ELISA), indirect immunofluorescent antibody test (IFAT) and immunochromatographic strip test ${ }^{24}$ as described elsewhere ${ }^{20}$. Briefly, IFAT was performed using promastigotes of Leishmania (L). amazonensis (MHOM/BR/1960/BH6) and the samples were considered positive if fluorescence was observed at 1:40 dilution. The crude antigen used in ELISA was obtained from the same $L$. amazonensis strain used for IFAT. Antibodies were detected with goat conjugated peroxidase-labeled anti-human IgG (Sigma Co, US) and the reactions were read at $492 \mathrm{~nm}$. The cut-off value was established as the mean absorbancy value +2 standard deviations from 20 known negative sera at a 1:80 dilution. The strip test was performed using blood eluted from filter paper. The test was only considered to be positive if the results obtained by three independent readers were in agreement.

Briefly, in 1,604 eluates examined, 171 (10,7\%) were reactive in at least one test, $11(6,4 \%)$ in two tests; no eluate was simultaneously reactive in three techniques. The concordance between ELISA and IFAT was poor $(\mathrm{kappa}<0.20)$ and strip test did not show any agreement with either IFAT or ELISA.

A subset of 226 participants was invited for re-evaluation one year later, including 102 seropositives (all positive in ELISA or IFAT and $50 \%$ of those reactive in strip test) plus 124 serological negative participants. The decision to include $50 \%$ of positive strip test individuals in follow up was due to the poor agreement of the test reproducibility and the high discordance with ELISA or IFAT results. The positive strip test samples were randomly chosen among those positive in this test. The aim was to increase the sensibility of the screening phase.

This phase was conducted at the outpatient clinic of the General Carneiro public health service. Blood was collected by venipuncture in a vacuum tube; a clinical examination was performed, the information being collected in a standardized form. The participants were also re-interviewed using a pre-coded questionnaire to identify personal characteristics and risk factors related to the infection. Nutritional status was evaluated based on measurements of height and weight. The serologic tests performed were IFAT and ELISA using L. amazonensis antigen and the recombinant antigen rk394. Molecular methods included polymerase chain reaction (PCR) and hybridization with a specific probe to $L$. donovani complex ${ }^{13}$. DNA was extracted 
by phenol-chloroform:isoamyl alcohol and ethanol precipitated, resuspended in $30 \mu \mathrm{l}$ low TE buffer and stored at $4^{\circ} \mathrm{C}$. A pair of primers were used to amplify a fragment of $120 \mathrm{bp}$ of the conserved region of Leishmania kDNA minicircle [5(G/C) $(\mathrm{G} / \mathrm{C})(\mathrm{C} / \mathrm{G}) \mathrm{CC}(\mathrm{A} / \mathrm{C}) \mathrm{CTAT}(\mathrm{A} / \mathrm{T})$ TTACACAACCCC - 3 ' and 5'- GGGAGGGGCGTTCTGCGAA - 3'] as described previously ${ }^{20}$. The reaction products were visualized in $5 \%$ polyacrylamide gel electrophoresis stained with $\operatorname{silver}^{23}$. Probes composed of cloned minicircles from $L$. chagasi radiolabeled with ${ }^{32} \mathrm{P}$ - [a]dCTP using the Random Primer DNA Labeling System (Gibco BRL) were used for hybridization of the amplified products ${ }^{2}$. True negative and positive controls (confirmed by clinical, parasitolologic, serologic and molecular tests) were included in all diagnostic tests performed. Negative samples were tested for the human ß-globin gene to confirm that DNA was not degraded and that inhibition in PCR exams had not occurred. Procedures to avoid carryover contamination from previously amplified DNA were used routinely ${ }^{17}$.

Criteria for $\boldsymbol{L}$. chagasi infection. In follow up phase, 130 $(57,5 \%)$ were positive in at least one serological test. However, the agreement was poor among the tests $($ kappa $<0.20)$. Comparison between serological and molecular diagnostic methods also showed discordance. Among 133 positive samples in the hybridization 59 (44.4\%) were negative in all serological tests performed. Regarding the 93 negative samples in the hybridization, 56 (60.2\%) were reactive in serological tests. On the other hand, the evaluation of tests reproducibility (duplicates blindly carried out) showed a good agreement for PCR (kappa 0.89, 95\% CI 0.67-1.0) and IFAT (kappa 0.74, 95\% CI 0.401.0), regular for ELISA (kappa 0.53, 95\% CI 0.18-0.89) and poor agreement for strip test (kappa 0.14, 95\% CI -0.11-0.40).

Due to this discordance different criteria were proposed to define asymptomatic $L$. chagasi infection in the follow-up phase ${ }^{20}$. In the present study two criteria were tested to identify risk factors associated with asymptomatic infection. Model 1: infected individuals were considered those presenting a positive hybridization. Model 2: infection was defined by positive hybridization and serology; this model included all positive hybridization participants presenting at least one reactive serologic test.

Study variables. The final version of the questionnaires defined after a pilot test, included: (1) demographic variables; (2) socioeconomic status; (3) household characteristics including all annexes, buildings and waste in the back yard; (4) domestic refuse storage and disposal; (5) wastewater disposal; (6) existence of eroded areas near the house; (7) presence of domestic animals; (8) knowledge of human and canine leishmaniasis and vectors; (9) factors related to control measures. The interviewer was trained and used an instruction manual to guarantee reliability in data collection.

The following aspects were evaluated in the clinical examination: (1) symptoms and signs related to leishmaniasis; (2) current and past illness; (3) demands on health services (hospitalization and clinical examination).

Malnutrition. Children's weights and heights for age were analysed according to the population pattern of the Reference National Center Health Statistics, using EPI-NUT/EPI-INFO (version 6.04d). Participants who were more than ten years old were evaluated using the ratio of weight to squared height.
Data analysis. Analysis of risk factors for Leishmania chagasi infection was performed for the subset of 226 participants included in the follow-up phase. The analysis was conducted considering two models to define $L$. chagasi infection that have been described above. The data set was organized using EpiInfo and statistical analysis was performed using STATA statistic software version 7.0 (Stata Corporation, 2001).

The sequence of the statistical analysis followed these steps: Univariate analysis was performed for each model using $\chi^{2}$ (proportions) and tests for means and medians (t-test and Wilcoxon); odds ratio (OR) and $95 \%$ confidence intervals were used to quantify the association between single putative risk factors and L. chagasi infection. Multivariate analyses were performed using logistic regression model in the following sequence ${ }^{14}$ : 1) preliminary selection of the variables from the univariate analysis included those at $\mathrm{p} \leq 0.20$ and those considered biologically important for $L$. chagasi infection based on literature. Variables that reached statistical significance on that level but presented colinearity or low frequency were excluded from the multivariate analysis. Categorical variables were transformed in dummies; 2) construction of intermediate logistic models using different homogeneous subgroups (demographic and social variables, characteristics of household and annexes, vector-related variables, presence of animals and clinical variables). Variables attaining a significance levels of $\mathrm{p} \leq 0.15$ were retained in these models; 3 ) construction of a final model, maintaining only those variables that reached significance levels of $\mathrm{p} \leq 0.05$ and $95 \%$ confidence intervals. At each step of the intermediate and final models new models were constructed using the backward process and statistical significance was determined by likelihood ratio tests ${ }^{14}$.

\section{RESULTS}

A total of 440 households were selected and blood samples were obtained, on filter paper, from 1,604 inhabitants $(8.2 \%$ of General Carneiro population). The mean age of the study population was 26.8 ( \pm 18.6 ) years; the median age was 23 years $(25 \%$ and $75 \%$ inter-quartile range 13 and 38 , respectively); $51.7 \%$ were female; $69.7 \%$ had only elementary school education and $9.8 \%$ had never gone to school. The mean period of residence in this area was $15( \pm 11.2)$ years. Most participants $(72.8 \%)$ were born in the metropolitan area of Belo Horizonte and $70.5 \%$ had never lived in any other area The mean monthly income per family was $3.7 \pm 2.9$ Brazilian minimum wages (Brazilian monthly minimum wage $=\mathrm{U} \$ 70)$.

Signs and symptoms related to visceral leishmaniasis were neither observed nor reported during clinical examination. Only six participants (one child) showed low hematocrit $(<30 \%)$, but without significant differences in all other clinical criteria to define infection (fever, hepatomegaly and/or splenomegaly and weight loss).

The characteristics of the study households were as follows: $26.1 \%$ had unplastered walls and 38\% cement floors; $2.7 \%$ of the houses had no indoor bathroom and $1.6 \%$ had poor sanitary installations (open sewer). In $72.3 \%$ of the houses garbage was collected by the public system. The main types of construction present in backyards were kennels (28\%) and chicken houses (22.3\%). Trees were found 
in $81.8 \%$ of these yards. Plants rooted in the soil were found in $73.9 \%$ of yards and in vases in $71.8 \%$. Other features included piles of bricks (58.6\%), garbage (56.4\%), stones (50.2\%) and organic materials in decomposition such as leaves and tree trunks $(39.8 \%)$.

Environmental conditions near the houses were urban, with other dwellings surrounding most of the houses, except for occasional adjoined natural vegetation $(29.8 \%)$ or eroded areas $(17.1 \%)$.
Criterion 1 of Leishmania chagasi infection (positive for hybridization). This analysis compared 133 positive and 93 negative individuals for hybridization. Univariate analysis was performed considering all the variables collected by interview and in the clinical examination (data not shown). The selected variables that attained a significance level of 0.20 in univariate analysis are shown in Table 1. These variables were included in intermediate logistic models for each group of variables (data not shown). Age and sex were also included, since these are

Table 1 - Distribution of the selected variables in univariate analysis according to model 1 (General Carneiro - Sabará/MG, 1998 ).

\begin{tabular}{|c|c|c|c|c|c|c|}
\hline \multirow[t]{2}{*}{ Variables } & \multicolumn{2}{|c|}{ Infected $(\mathrm{n}=133)$} & \multicolumn{2}{|c|}{ Uninfected $(n=93)$} & \multirow[t]{2}{*}{ OR (CI 95\%) } & \multirow[t]{2}{*}{ p-value } \\
\hline & $\mathrm{n}^{0}$ & $\%$ & $\mathrm{n}^{0}$ & $\%$ & & \\
\hline \multicolumn{7}{|l|}{ Age groups } \\
\hline$>10$ & 97 & 72.9 & 63 & 67.7 & $1.3(0.7-2.3)$ & 0.398 \\
\hline \multicolumn{7}{|l|}{ Gender } \\
\hline \multicolumn{7}{|l|}{ Race } \\
\hline black & 27 & 20.3 & 16 & 17.2 & 1 & \\
\hline mulatto & 80 & 60.2 & 48 & 51.6 & $1.0(0.5-2.0)$ & 0.973 \\
\hline white & 26 & 19.6 & 29 & 31.2 & $0.5(0.2-1.2)$ & 0.128 \\
\hline \multicolumn{7}{|l|}{ Persons per bedroom } \\
\hline one or two & 99 & 74.4 & 53 & 58.2 & 1 & \\
\hline three or more & 34 & 25.6 & 38 & 41.8 & $0.5(0.3-0.8)$ & 0.011 \\
\hline \multicolumn{7}{|l|}{ Type of wall covering } \\
\hline unplastered & 6 & 4.5 & 9 & 9.7 & 1 & \\
\hline plastered & 103 & 77.4 & 73 & 78.5 & $2.1(0.7-6.3)$ & 0.165 \\
\hline mixed & 24 & 18.1 & 11 & 11.8 & $3.3(0.9-12.2)$ & 0.061 \\
\hline \multicolumn{7}{|l|}{ Destiny of Garbage } \\
\hline collected (not vs yes) & 47 & 35.3 & 16 & 17.2 & $2.6(1.4-5.0)$ & 0.003 \\
\hline \multicolumn{7}{|l|}{ Annexes (yes vs no) } \\
\hline erosion sites (yes vs no) & 23 & 17.4 & 24 & 25.8 & $0.6(0.3-1.2)$ & 0.128 \\
\hline \multicolumn{7}{|l|}{ Whereabouts 6:00-10:00 PM } \\
\hline outdoors vs indoors & 42 & 31.6 & 18 & 19.4 & $1.9(1.0-3.6)$ & 0.041 \\
\hline \multicolumn{7}{|l|}{ Insecticide use } \\
\hline no vs yes & 31 & 23.3 & 40 & 43.0 & $0.4(0.2-0.7)$ & 0.002 \\
\hline \multicolumn{7}{|l|}{ Animal presence (yes vs no) } \\
\hline $\operatorname{dog} s$ & 82 & 61.7 & 45 & 48.4 & $1.7(1.0-2.9)$ & 0.048 \\
\hline cagebirds & 67 & 50.4 & 22 & 23.7 & $3.3(1.8-5.9)$ & 0.000 \\
\hline chickens & 52 & 39.1 & 25 & 26.9 & $1.7(1.0-3.1)$ & 0.057 \\
\hline \multicolumn{7}{|l|}{ Dogs with short hair } \\
\hline yes vs no & 65 & 48.9 & 37 & 39.8 & $1.4(0.8-2.5)$ & 0.177 \\
\hline \multicolumn{7}{|l|}{ Drinking alcohol (a) } \\
\hline yes vs no & 14 & 14.4 & 20 & 30.8 & $0.4(0.2-0.8)$ & 0.012 \\
\hline \multicolumn{7}{|l|}{ Presence of skin disease } \\
\hline yes vs no & 18 & 13.6 & 22 & 23.7 & $0.5(0.3-1.0)$ & 0.053 \\
\hline \multicolumn{7}{|l|}{ Liver palpable } \\
\hline yes vs no & 14 & 10.6 & 17 & 18.3 & $0.5(0.3-1.1)$ & 0.100 \\
\hline
\end{tabular}


known to be associated with $L$. chagasi infection. The variables included in the final model ( $\mathrm{p} \leq 0.15)$ were: race (white vs others), number of persons per bedroom (more than two vs less than two persons), house with plastered walls (yes vs no), garbage collected by the public system (no vs yes), insecticide use by the inhabitants (no vs yes), presence of chicken house (yes vs no), presence of chickens (yes vs no), time spent outside house between (6:0010:00 PM) (yes vs no), ownership of birds (yes vs no), ownership of dogs (yes vs no), presence of skin disease (yes vs no). The final model for this criterion of infection is shown in Table 2.

Table 2 - Risk factors for Leishmania chagasi infection according to model 1 (General Carneiro, Sabara, MG, Brazil).

\begin{tabular}{lcc}
\hline Variables & $\begin{array}{c}\text { Unadjusted } \\
\text { Odds Ratio } \\
(\text { CI 95\%) }\end{array}$ & $\begin{array}{c}\text { Adjusted } \\
\text { Odds Ratio } \\
\text { (CI 95\%) }\end{array}$ \\
\hline Ownership of cagebirds (yes vs no) & $3.3(1.8-5.9)$ & $3.1(1.7-5.7)$ \\
Outdoors between 6:00-10:00 PM (yes vs no) & $1.9(1.0-3.6)$ & $2.2(1.1-4.4)$ \\
Garbage collected by the public system (no vs yes) & $2.6(1.4-5.0)$ & $2.8(1.4-5.6)$ \\
Insecticide use (no vs yes) & $0.4(0.2-0.7)$ & $0.4(0.2-0.7)$
\end{tabular}

Criterion 2 of Leishmania chagasi infection (positive for hybridization plus at least one serologic test). This analysis compared 74 individuals positive for hybridization plus at least one serologic test and 152 individuals that were negative for this criterion. Univariate analysis was performed by taking into account all the variables collected by interview and clinical examinations (data not shown). Tables 3 shows the selected variables that attained a significance level of 0.20 in univariate analysis; age and sex were also included. These variables were included in intermediate logistic models (data not shown). The variables included in final model were: race (white vs others) birthplace (metropolitan region vs others), house with plastered walls (yes vs no), garbage collected by the public system (no vs yes), garbage removed or buried (no vs yes); time spent outside house between (6:00- 10:00 PM) (yes vs no); ownership of birds (yes vs no); ownership of dogs with short hair (yes vs no); presence of dogs with AVL in the home (yes vs no); family with knowledge of the vector (yes vs no); eroded areas in the neighbourhood (yes vs no), presence of organic material in backyard (yes vs no). The final model for this criterion of infection is shown in Table 4.

Table 3 - Distribution of the selected variables in univariate analysis according to model 2.

\begin{tabular}{|c|c|c|c|c|c|c|}
\hline Variables & \multicolumn{2}{|c|}{ Infected $(n=74)$} & \multicolumn{2}{|c|}{ Uninfected $(\mathrm{n}=152)$} & OR (CI 95\%) & $\mathrm{p}$-value \\
\hline \multicolumn{7}{|l|}{ Age group } \\
\hline $1-10$ & 22 & 29.7 & 44 & 28.9 & & \\
\hline$>10$ & 52 & 70.3 & 108 & 71.1 & $1.0(0.5-1.8)$ & 0.903 \\
\hline \multicolumn{7}{|l|}{ Gender } \\
\hline male & 33 & 44.6 & 74 & 48.7 & $0.8(0.5-1.5)$ & 0.563 \\
\hline \multicolumn{7}{|l|}{ Race } \\
\hline black & 15 & 20.3 & 28 & 18.4 & 1 & \\
\hline mulattoes & 46 & 62.2 & 82 & 54.0 & $1.0(0.5-2.2)$ & 0.901 \\
\hline others & 26 & 37.7 & 41 & 28.5 & $1.5(0.8-2.9)$ & 0.176 \\
\hline \multicolumn{7}{|l|}{ Persons per bedroom } \\
\hline one or two & 55 & 74.3 & 97 & 64.7 & & \\
\hline three or more & 19 & 25.7 & 53 & 35.3 & $0.6(0.3-1.2)$ & 0.145 \\
\hline \multicolumn{7}{|l|}{ Type of wall covering } \\
\hline unplastered & 4 & 5.4 & 11 & 7.2 & 1 & \\
\hline plastered & 54 & 73.0 & 122 & 80.3 & $1.2(0.4-4.0)$ & 0.746 \\
\hline mixed & 16 & 21.6 & 19 & 12.5 & $2.3(0.6-9.0)$ & 0.212 \\
\hline chicken house & 27 & 36.5 & 37 & 24.3 & $1.8(1.0-3.2)$ & 0.057 \\
\hline \multicolumn{7}{|l|}{ Materials in the yards } \\
\hline stones & 41 & 55.4 & 70 & 46.1 & $1.5(0.8-2.5)$ & 0.187 \\
\hline leaves, rotten tree trunks & 20 & 27.0 & 61 & 40.1 & $0.5(0.3-1.0)$ & 0.054 \\
\hline
\end{tabular}


Table 3-Continuation.

\begin{tabular}{|c|c|c|c|c|c|c|}
\hline \multirow[t]{2}{*}{ Variables } & \multicolumn{2}{|c|}{ Infected $(\mathrm{n}=74)$} & \multicolumn{2}{|c|}{ Uninfected $(n=152)$} & \multirow[t]{2}{*}{ OR (CI 95\%) } & \multirow[t]{2}{*}{$\mathrm{p}$-value } \\
\hline & $\mathrm{n}^{0}$ & $\%$ & $\mathrm{n}^{0}$ & $\%$ & & \\
\hline \multicolumn{7}{|l|}{ Peridomestic environment } \\
\hline eroded areas (yes vs no) & 9 & 12.2 & 38 & 25.2 & $0.4(0.2-0.9)$ & 0.024 \\
\hline \multicolumn{7}{|l|}{ Whereabouts 6:00-10:00 PM } \\
\hline outdoors vs indoors & 24 & 32.4 & 36 & 23.7 & $1.5(0.8-2.8)$ & 0.162 \\
\hline \multicolumn{7}{|l|}{ Family knowledge of the vector } \\
\hline yes vs no & 12 & 16.2 & 6 & 3.9 & $4.7(1.7-12.7)$ & 0.001 \\
\hline \multicolumn{7}{|l|}{ Insecticide use } \\
\hline no vs yes & 19 & 25.7 & 52 & 34.2 & $0.7(0.4-1.2)$ & 0.195 \\
\hline \multicolumn{7}{|l|}{ Animals present } \\
\hline $\operatorname{dogs}$ & 46 & 62.2 & 81 & 53.3 & $1.4(0.8-2.5)$ & 0.207 \\
\hline cagebirds & 38 & 51.4 & 51 & 33.6 & $2.1(1.2-3.7)$ & 0.010 \\
\hline chickens & 30 & 40.5 & 47 & 30.9 & $1.5(0.9-2.7)$ & 0.152 \\
\hline \multicolumn{7}{|l|}{ Dogs with short hair } \\
\hline yes vs no & 39 & 52.7 & 63 & 41.5 & $1.6(0.9-2.7)$ & 0.111 \\
\hline \multicolumn{7}{|c|}{ Dogs with leishmaniasis in the house } \\
\hline never & 49 & 66.2 & 108 & 75.0 & & \\
\hline yes & 25 & 33.8 & 36 & 25.0 & $1.5(0.8-2.8)$ & 0.171 \\
\hline \multicolumn{7}{|c|}{ Symptoms of dogs with leishmaniasis } \\
\hline wounds (yes vs no) & 13 & 65.0 & 17 & 46.0 & $2.2(0.7-6.6)$ & 0.169 \\
\hline \multicolumn{7}{|l|}{ Liver palpable } \\
\hline yes vs no & 3 & 4.1 & 28 & 18.4 & $0.2(0.1-0.6)$ & 0.004 \\
\hline
\end{tabular}

Data for refusals, don' t know, not done are not shown..

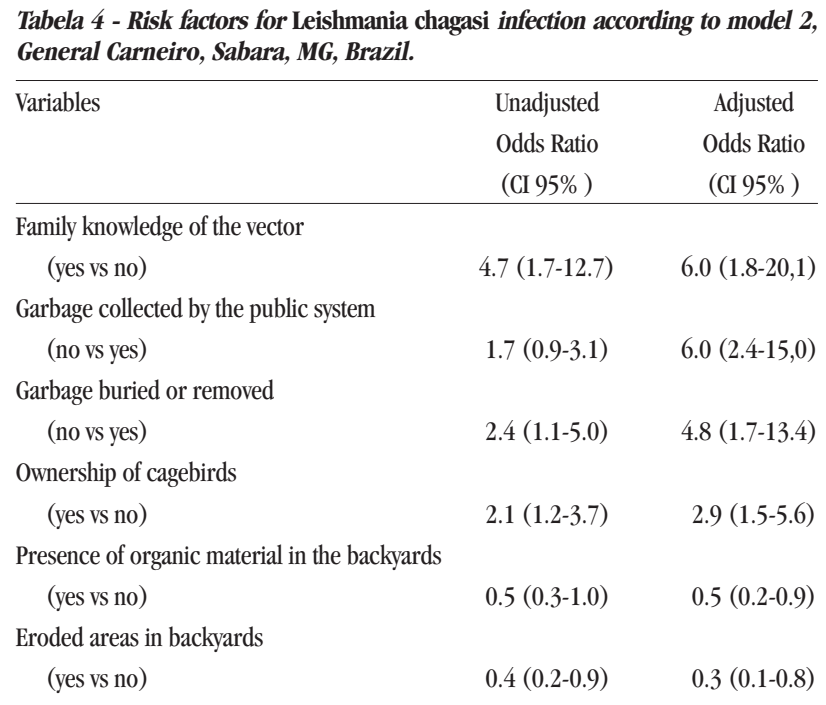

\section{DISCUSSION}

In this investigation, the variables that appeared to increase the risk of infection by L. chagasi in urban area found in the two models were: garbage not collected by the public system, garbage not buried or deposited outside the home, family reporting knowledge of the vector, eroded areas in the neighbourhood, time spent outside house between 6:00-10:00 PM and ownership of birds. Only two variables were similar in both models: garbage not collected by the public system and ownership of birds.
Our results show adjusted relative odds of 2.8 and 6.0 (Model 1 and 2, respectively) for those households whose garbage was not collected by the public system. Similar results $(\mathrm{OR}=4.8)$ were observed for those who did not remove or bury their garbage (Model 2). The cumulative waste that is typical of urbanized areas contributes to the presence of L. longypalpis ${ }^{29}$. Materials such as piles of bricks, stones and garbage have been described as a potential breeding and resting sites for sand flies ${ }^{28}$.

The results reveal adjusted odds of 3.1 (Model 1) and 2.9 (Model 2) for individuals who keep birds in their houses compared with those who did not report owning birds. The variable was not quantitatively evaluated and did not distinguish between different types of cagebirds. These birds could provide an abundance of blood meals for female sand flies and help increase vector population densities in the peridomestic environment ${ }^{3}$. No association was observed between $L$. chagasi infection and the presence of chickens or chicken houses. Although chickens and other birds cannot act as Leishmania reservoirs because they are refractory to infections, they may be important in maintaining vector populations near houses $^{112} 2829$. Moreover, the role chickens play in L. chagasi transmission has not been resolved ${ }^{1}$.

The adjusted odds ratio for those individuals with families who claimed to recognize the vector was six times higher than those with no knowledge of sand flies (Model 2). Vector recognition was acknowledged by self-reporting and validated by showing different diptera species samples (L. longipalpis, Aedes aegypti and Drosophila $s p$ ) to the participants. This variable can be understood as an indirect measure of exposure to phebotomines and shows the importance of using proxy 
variables to identify risk factors ${ }^{16}$. Among the study population, $8 \%$ of the families reported having knowledge of sandflies, and some of them used common names for the insects.

For those individuals who reported being outside the house between 6:00-10:00 PM, the adjusted odds ratio was two-fold higher than with those reported staying indoors during this period (Model 1). This suggests that the transmission may be occurring outside the home in the early evening. The vector $L$. longipalpis is a peridomestic sandfly that takes blood from a variety of hosts. Since chickens and other potential bloodmeal sources may be scarce in some urban areas, this species has no clear host preferences. Similar results were observed in Northeast Brazil, where bathing outside the house and playing outdoors between 6:00-10:00 PM were identified as risk factors for infection in children under five years old ${ }^{7}$.

Residents of houses near erosion sites, where vegetation cover has been removed, have a lower risk of infection $(\mathrm{OR}=0.3$ in Model 2 ). The AVL has generally been associated with rural areas and in some urban zones areas, the transmission has been observed on the fringes of large Brazilian cities where small patches of forest still remain. In these areas unplanned urbanization, colonization by low-income earners and rapid devastation of natural environment may create favourable conditions for phebotomines ${ }^{28}$. Sporadic AVL cases also have been recorded in other parts of the metropolitan region of Belo Horizonte, including central areas with little or no natural vegetation cover $^{2021}$.

Two other variables associated with $L$. chagasi infection merit further consideration. First, the presence of organic material in the yards was associated with absence of infection. The adjusted relative odds was 0.5 (Model 2) for individuals whose dwellings had organic material in their yards. This variable was based on the presence of fallen leaves, rotten tree, trunks and other decomposing material. Although the natural breeding sites of $L$. longipalpis are barely known, oviposition of sand flies and development of their larvae occur in humid, shady microhabitats rich in organic material ${ }^{12} 18$.

Second, the absence of insecticide use by the inhabitants was found to be a protective factor $(\mathrm{OR}=0.4$ in Model 1$)$. Unfortunately, insecticide use was too imprecisely measured; different formulations (household aerosol cans, electric spraying equipment), and other product types (orange peel, citronella, etc.) were reported as being used by the inhabitants. More investigation is needed to resolve those queries.

Our results conform to a study carried out on asymptomatic children in Northeast Brazil, where different outcome measures were used to identify AVL infection ${ }^{7}$. In this study the presence of sandflies, dogs or chickens in the house or in the neighborhoods tended to increase the risk of asymptomatic infection when skin tests were used to identify infection, whereas these same variables appeared to be protective when ELISA was used.

The spread and increasing incidence of AVL in Brazilian urban areas has been attributed to human migrations, involving the transportation of infected dogs from endemic regions to peripheral suburbs of large cities and impoverished urban areas where $L$. longipalpis already exists ${ }^{1}$ 325 . However, about $70 \%$ of our study population was born and had always lived in the same area, with a mean residence time of about 15 years and, therefore was considered stable.
The presence of infected dogs in households was not associated with human infection in our study. The lack of association is probably due to the proximity of houses in urban areas. The presence of infected dogs in one house is thus shared with neighbouring dwellings. Ecological studies using spatial analysis showed an association between incidence of human AVL and seropositivity in dogs between 1994 and 1997 in Belo Horizonte $^{21}$. A strong correlation was also found when we compared our data of the human infection using city blocks as units of analysis and the information of infected dogs obtained from the local health services ${ }^{9}$.

The present AVL control strategies in Brazil are based on the occurrence of symptomatic cases, and the majority of studies have identified risk factors associated with disease progression. It is important from a public health perspective to understand the role of asymptomatic cases in maintaining the infection and the risk factors associated with infection in urban areas. It is becoming clear that asymptomatic infections can be a significant aspect of AVL epidemiology 2027.

The inconsistencies found in our investigation are due to: 1) misclassification bias of the outcomes may have occurred because we used criteria with different sensitivities and specificities. Such a strategy was used because there was a disagreement in the diagnostic techniques applied to identify infection in the present investigation ${ }^{20}$. Our results confirm the absence of a gold standard technique to confirm active $L$. chagasi infection in asymptomatic individuals. The two criteria proposed present advantages and limitations ${ }^{20}$. The hybridization seems to have the better sensitivity and specificity and was used as a reference for infection in Criterion 1. On the other hand, individuals that were positive only in the serologic tests were not considered in the risk factor analysis. This decision take into account that reactive serology could be understood as cross-reactivity with other diseases or past infections. The disadvantage of Criterion 2 was to include individuals with positive hybridization in the negative group. The use of different diagnostic methods identified different risk factors for $L$. chagasi infection. 2) respondent and observer bias with respect to some of the environmental variables may have occurred. Variables based on yard characteristics, as well as the presence of animals and infected dogs, were not quantified. To minimise the occurrence of this kind of bias the interviewers were trained and an instruction manual was used to collect information. Finally, inclusion of existing infected cases into the study and lack of information on the timing of infection (prevalence bias), exposure to the presumed risk factors and the outcome (temporal bias) are biases typical of cross-sectional analyses.

In short, the risk factors identified for L. chagasi infection in an urban area were associated with household conditions, presence of animals and the likelihood of contact with phlebotomine sandflies. This is probably due to environmental characteristics that favor vector breeding and blood feeding in the vicinity of houses. 


\section{ACKNOWLEDGMENTS}

We are grateful to the Secretaria Municipal de Saúde de Sabará, Minas Gerais and Fundação Nacional de Saúde, Minas Gerais, for their cooperation and logistic support.

\section{REFERENCES}

1. Alexander B, Carvalho RL, McCallum H, Pereira MH. Role of the domestic chicken (Gallus gallus) in the epidemiology of urban visceral leishmaniasis in Brazil. Emerging Infectious Disease 8:1480-1485, 2002.

2. Andrade ASR,Gomes RF, Fernandes 0, Melo MN. Use of DNA-based diagnostic methods for human leishmaniasis in Minas Gerais, Brazil. Acta Tropica 78:261-267, 2001.

3. Arias JR, Monteiro P, Zicker F. The reemergence of visceral leishmaniasis in Brazil. Emerging Infectious Diseases 2:145-146, 1996.

4. Badaró R, Benson D, Eulálio MC, Freire M, Cunha S, Netto EM, PedralSampaio D, Madureira C, Burns JM, Houghton RL, David JR, Reed SG. rk39: A cloned antigen of Leishmania chagasi that predicts active visceral leishmaniasis. Journal of Infectious Diseases 173:758-761, 1996.

5. Badaró R, Jones TC, Carvalho EM, Sampaio D, Reed SG, Barral A, Teixeira $\mathrm{R}$, Johnson Jr WD. New perspectives on a subclinical form of visceral leishmaniasis. Journal of Infectious Diseases 154:1003-1011, 1986a.

6. Badaró R, Jones TC, Lorenço R, Cerf J, Sampaio D, Carvalho EM, Rocha H, Teixeira R, Johnson Jr WD. A Prospective Study of Visceral Leishmaniasis in an Endemic Area of Brazil. Journal of Infectious Diseases 154:639-649, $1986 \mathrm{~b}$.

7. Caldas AJM, Costa JML, Silva AAM, Vinhas V, Barral A. Risk factors associated with asymptomatic infection by Leishmania chagasi in north-east Brazil. Transactions of the Royal Society of Tropical Medicine and Hygiene 95:1-8, 2001a.

8. Caldas AJM, Silva DRC, Pereira CCR, Nunes PM, Silva BP, Silva AAM, Barral A, Costa JML. Infecção por Leishmania (Leishmania) chagasi em crianças de uma área endêmica de leishmaniose visceral americana na Ilha de São Luiz- MA, Brasil. Revista da Sociedade Brasileira de Medicina Tropical 34: 445-451, 2001b.

9. Callado ES, Moreno EC, Antunes CM, Wilke VML, Carneiro M. Correlação entre a infecção humana assintomática por Leishmania chagasi e a infecção canina em General Carneiro, Sabará, Minas Gerais. Revista da Sociedade Brasileira de Medicina Tropical 34: (Supl III): 151-152, 2001.

10. Costa CHN, Vieira JBF. Mudanças no controle da leishmaniose no Brasil. Revista da Sociedade Brasileira de Medicina Tropical 34:223-228, 2001.

11. D'Oliveira Jr A, Costa SRM, Barbosa AB, Orge MLG0, Carvalho EM. Asymptomatic Leishmania chagasi infection in relatives and neighbors of patients with visceral leishmaniasis. Memórias do Instituto Oswaldo Cruz. Rio de Janeiro 92: 15-20, 1997.

12. Deane LM, Deane MP. Visceral leishmaniasis in Brazil: geographical distribution and transmission. Revista do Instituto de Medicina Tropical de São Paulo 4:198-212, 1962.
13. Degrave W, Fernandes O, Campbell D, Bozza M, Lopes U. Use of molecular probes and PCR for detection and typing of Leishmania-a mini-review. Memórias do Instituto Oswaldo Cruz 89:463-469, 1994.

14. Hosmer Jr DW, Lemeshow S. Applied Logistic Regression. John Wiley \& Sons, New York, 1999.

15. Jeronimo SMB, Teixeira MJ, Sousa AP, Thielking P, Pearson RD, Evans TG. Natural history of Leishmania (Leishmania) chagasi infection in Northeastern Brazil: long-term follow-up. Clinical Infectious Diseases 30:608-609, 2000.

16. Kelsey JL, Whittemore AS, Evans AS, Thompson WD. Methods in Observational Epidemiology. Oxford University Press, Oxford, 1996.

17. Kwok S, Higuchi R. Avoiding false positives with PCR. Nature 339: 237-238, 1989.

18. Lainson R. The American leishmaniasis: some observations on their ecology and epidemiology. Transactions of the Royal Society of Tropical Medicine and Hygiene 77:569-596, 1983.

19. Luz ZMP, Pimenta DN, Cabral ALV, Fiúza VOP, Rabello A. A urbanização das leishmanioses e a baixa resolutividade diagnóstica em municípios da Região Metropolitana de Belo Horizonte. Revista da Sociedade Brasileira de Medicina Tropical 34:249-254, 2001.

20. Moreno EC. Epidemiologia da leishmaniose visceral humana em área urbana de Minas Gerais: identificação da infecção assintomática e seus fatores de risco. Tese de doutorado. Universidade Federal de Minas Gerais, Belo Horizonte, MG, 2002.

21. Oliveira CL, Assunção RM, Reis IA, Proietti FA. Spatial distribution of human and canine visceral leishmaniasis in Belo Horizonte, Minas Gerais State, Brazil, 1994-1997. Cadernos de Saúde Pública 17:1231-1239, 2001.

22. Pampiglione S, Manson-Bahr PEC, Giuingi, F, Giunti G, Parenti A, Canestri Trotti G. Studies on Mediterranean leishmaniasis. 2. Asymptomatic cases of visceral leishmaniasis. Transactions of the Royal Society of Tropical Medicine and Hygiene 68:447-453, 1974.

23. Santos FR, Pena SDJ, Epplen JT. Genetic and population study of a Y-linked tetranucleotide repeat DNA polymorphism with a simple non-isotopic technique. Human Genetics 90:655-656, 1993.

24. Sundar S, Reed SG, Singer V, Kumar P, Murray H. Rapid accurate field diagnosis of Indian visceral leishmniasis. The Lancet 351:563-565, 1998.

25. Tesh R. Control of zoonotic visceral leishmaniasis: is it time to change strategies? American Journal of Tropical Medicine and Hygiene 52:287-292, 1995.

26. Vieira JBF, Coelho GE. Leishmaniose visceral ou calazar: aspectos epidemiológicos e de controle. Revista da Sociedade Brasileira de Medicina Tropical 31:85-92, 1998.

27. Werneck GL, Rodrigues Jr L, Santos MV, Araújo IB, Moura LS, Lima SS, Gomes RBB, Maguirre JH, Costa CHN. The burden of Leishmania chagasi infection during an urban outbreak of visceral leishmaniasis in Brazil. Acta Tropica 83:13-18, 2002.

28. Wijeyaratne PM, Jones Arsenault LK, Murphy CJ. Endemic disease and development: the leishmaniases. Acta Tropica 56:349-364, 1994.

29. World Health Organization Expert Committee. Control of leishmaniasis. World Health Organization. Geneva, WHO Technical Report Series, № 793, 1990. 